\title{
Adult Brain Neoplasm
}

National Cancer Institute

\section{Source}

National Cancer Institute. Adult Brain Neoplasm. NCI Thesaurus. Code C7710.

A benign or malignant, primary or metastatic neoplasm of the brain occurring in adults. 